International Journal of Business Management and Economic Review

Vol. 4, No. 04; 2021

ISSN: 2581-4664

\title{
THE EFFECT OF THE E-WOM DIMENSIONS OF THE INSTAGRAM ACCOUNT "KULINERATJEH" IN BANDA ACEH CITY ON BUYING INTENTION WITH BRAND IMAGE AS A MODERATING VARIABLE
}

\author{
*Nanda Khalisa, Permana Honneyta Lubis and Sorayanti Utami \\ Management Department, Universitas Syiah Kuala, Indonesia \\ http://doi.org/10.35409/IJBMER.2021.3287
}

\begin{abstract}
This study intends to examine the effect of the e-WOM dimension of the "kulineratjeh" Instagram account in the city of Banda Aceh on buying intention with the brand image as a moderating variable. The population of this study was Instagram account users in Banda Aceh. The sampling technique was the non-probability sampling method, and a sample of 208 people was obtained. This study used the MRA (Moderate Regression Analysis) method as the data analysis technique. The test results prove that the quality of e-WOM, the quantity of e-WOM, and the expertise of the reviewer are dimensions of e-WOM which are also as predictors of buying intention on products promoted on the Instagram account "kulineratjeh". This means that before people make a purchase, they first consider the three predictors. Of the three predictors, the variable quantity of e-WOM is the most dominant variable in influencing buying intention. Brand image moderates the effect of e-WOM quality, e-WOM quantity, and reviewer expertise on buying intentions for products promoted on the Instagram account "kulineratjeh". The role of brand image in this model is asQuasi Moderation, so the presence of a brand image can help strengthen the quantity of e-WOM and the quality of e-WOM on buying intentions. The findings can be used as an academic reference and future researchers are expected to be able to develop this tested model by adding other moderating variables such as brand awareness and gender.
\end{abstract}

Keyword: E-WOM, buying intention, Brand Image.

\section{INTRODUCTION}

The presence of the internet causes information to just spread without any limitations of space and time. This is what is currently being used by the community so that the activities carried out become more efficient. By seeing and feeling the benefits obtained from technology and the internet, technology and the internet are increasingly in demand so that growth and internet users also increase rapidly every year. This has also led to the development of social media throughout the world, including Indonesia. The existence of social media (social media) has made it easier for people to create, obtain and disseminate various information both in the form of images and videos so that the information displayed becomes clearer. Social media has also been able to help entrepreneurs to be more creative and innovative in running their business and can also increase buying intentions from consumers.

Of the many types of social media, Instagram is one of the most popular types of social 


\section{International Journal of Business Management and Economic Review}

Vol. 4, No. 04; 2021

ISSN: 2581-4664

media or the most sought after by users, especially in Indonesia. This requires business people to have an account on this type of social media to promote the type of business they are doing. By using Instagram, entrepreneurs can provide specific information for consumers about the condition of a product where this can be done by posting photos or videos related to the product. Information about the product can also be explained specifically through the photo or video caption posted. Consumers or potential consumers can also provide comments about these products through the comments column on Instagram. So that promotional activities through Instagram social media can also lead to communication following the photos of products or services that have been shared.

Communication activities that occur on Instagram can be seen through comments on the photo or video posts which causes word of mouth (WOM) to occur in online or electronic form so that it is better known as electronic word of mouth (e-WOM). Many research results have proven that e-WOM has a positive influence on buying intention and brand image. Today's technological developments also make consumers very selective in choosing a product, where they often seek information first and review a product or brand before making a purchase. Another thing is that the opinions given by consumers in the comments column are also a separate assessment for consumers to choose the products offered. This is also found on the Instagram account "kulineratjeh" which is an Instagram account that provides information about the number one culinary in Aceh.

This Instagram account, which has more than 136 thousand followers, contains reviews or provides recommendations and provides information about culinary tourism in Aceh. This Instagram account has become a trendsetter for culinary lovers in Aceh as well as for culinary entrepreneurs in Banda Aceh and its surroundings. Having a fairly large number of followers causes business actors to want to do paid promotions on the "kulineratjeh" Instagram account. Since 2014 until now, the Instagram account "kulineratjeh" has posted 6,716 culinary photos. From these posts, there are more than 100 types of culinary businesses that carry out paid promotions on the "kulineratjeh" Instagram account. Its purpose is to leave a review on the products offered.

The online popularity of a restaurant is very important because the online popularity of a restaurant can reflect the potential demand for the product in the future. It is believed that online product reviews play an important role in consumer buying decisions. Not all business owners who carry out paid promotions on the "kulineratjeh" Instagram account join as Go Jek or Grab partners in the form of Go Food or Grab Food. Even though the participation of culinary entrepreneurs on the platform can also increase consumer buying intentions so that business turnover also increases. The reason business actors do not join in the introduction application is that they are more focused on dine-in services. In addition, another consideration is that they maintain affordable prices for consumers considering that joining the delivery application will result in price increases both in terms of product prices and shipping costs, so they prefer to do promotions through the "kulineratjeh"Instagram account. Because this phenomenon makes researchers want to know more about the impact of e-WOM that occurs on the Instagram account "kulineratjeh" on consumers' buying intentions and brand image as a moderating variable.

\section{LITERATURE STUDY}


International Journal of Business Management and Economic Review

Vol. 4, No. 04; 2021

ISSN: 2581-4664

\section{Buying intention}

Buying intention is a psychological force that exists within the individual, which has an impact on taking an action(Schiffman \& Wisenblit, 2019). While(Kotler \& Armstrong, 2017)definedbuying intention as a decision to buy a brand among various other brands. In addition, the notion of buying intention according to (Tariq, Nawaz, Nawaz, \& Butt, 2013)is the consumer's primary act of buying a product when making a trip to the market. (Kotler \& Keller, 2018)explained that consumer behavior determines consumer buying intentions.(Kotler \& Armstrong, 2008)explained the elements of consumer buying intention caused by attention, interest, desire, and action which is now known as AIDA which is now developing into attention, interest, search, action, and sharing or better known as AISAS.

Based on the above understanding, it can be concluded that buying intention is a consumer's psychological behavior in the form of a plan in which the consumer makes a purchase. In this research, the measurement of buying intention uses indicators as revealed by(Schiffman \& Kanuk, 2010)i.e. interested in finding information about the product, considering buying, interested in trying, wanting to know about the product, and wanting to own the product.

\section{Electronic Word of Mouth (e-WOM)}

e-WOM is communication between consumers via the internet(Goldsmith \& Horowitz, 2006). According to(Bambauer-Sachse \& Mangol, 2011), e-WOM is a conversation between consumers about products that occurs on the internet. According to(Park \& Kim, 2008), e-WOM can be measured because comments on a product are written and available on the website. Therefore, e-WOM has great potential to help product transition from the initial market to the more inclined market if it is managed properly.

In this research, the measurement of e-WOM uses 3 dimensions(Lin, Wu, \& Chen, 2013)namely: 1) Quality of e-WOM, with indicators namely : the online review or ministry of a product is clear, online reviews or comments can be understood, online reviews or comments, online reviews or comments are very helpful, online reviews or comments can be trusted, reviews or comments online have strong reasons to support the opinion, and in general the quality of each review or comment online is high. This indicator was chosen because it fits the conditions and the research model; 2) The quantity of e-WOM, with an indicator : the number of reviews or online comments that conclude the product is popular, the number of good reviews or online comments concludes that the product has a good level of sales and the number of reviews or online comments that exist as a whole concludes that the product it has a good reputation, and; 3) reviewer expertise, with indicators : the person who submits a review is experienced, the person who submits a review has a lot of knowledge about the product, The person who submits a review has the ability to decide, the person who submits a review gives a different idea from other sources, and the person who submitted the review mentions a few things that I don't need to consider anymore

\section{Brand Image}

According to(Sangadji \& Sopiah, 2014), a brand image is a unique set of associations that marketers want to create or maintain. The associations state what the brand really is and what it promises to consumers. According to(Kotler \& Keller, 2018), Brand image is a set of brand 
associations that are formed in the minds of consumers. According to(Kotler \& Armstrong, 2017), Brand image is the set of consumer beliefs about various brands.

In this research, measurement of brand image uses indicators as expressed by(Kotler \& Keller, 2018)namely being able to recognize the "kulineratjeh" Instagram account through the logo, the "kulineratjeh" Instagram account having more interesting posts than other culinary review accounts, Getting to know the restaurants/cafes in Banda Aceh through the Instagram account "kulineratjeh", a culinary reference that first to remember, Have complete information about the restaurant/cafe, The quality of the information is up to date, Happy with the services provided.

\section{Conceptual Framework}

The conceptual framework of this research can be described as follows :

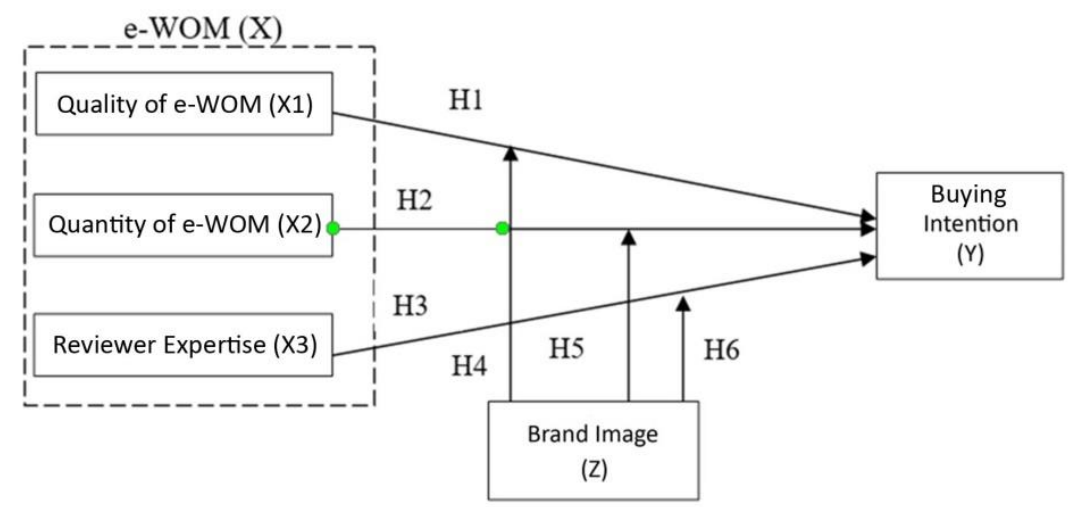

Figure 1. Conceptual Framework

H1 : The quality of e-WOM on the Instagram account "kulineratjeh" affects consumers' buying intentions.

H2 : The quantity of e-WOM on the Instagram account "kulineratjeh" affects consumers' buying intentions.

H3 : The skill of sending the Instagram account "kulineratjeh" affects consumers' buying intentions.

H4 : Brand Image moderates the effect of the e-WOM quality of the Instagram account "kulineratjeh" on consumers' buying intentions.

H5 : Brand Image moderates the effect of the quantity of e-WOM on the Instagram account "kulineratjeh" on consumers' buying intentions.

H6 : Brand Image moderates the effect of the expertise of the reviewer of the Instagram account "kulineratjeh" on consumers' buying intentions.

\section{RESEARCH METHOD}

The research was conducted to determine the effect of e-WOM on the "kulineratjeh" Instagram account on buying intention with the brand image as a moderating variable related to theory development in marketing science. This type of research was explanatory research, namely to test hypotheses in order to get answers to a problem or assumption. The research was conducted in Banda Aceh City and the population is Instagram account users in Banda Aceh. 
The technique used in the sampling was the non-probability sampling method, which did not provide equal opportunities for each element (member) of the population to be selected as a sample member(Sugiyono, 2017).Furthermore, the type of sampling technique used was purposive sampling because the researcher did not have data on the population in the form of a sample frame, so the criteria for fulfilling the purposive sampling technique used were:

1) Respondents have an Instagram account and follow the Instagram account "kulineratjeh".

2) Respondents are people who are looking for culinary reviews in Banda Aceh through the Instagram account "kulineratjeh".

3) The respondent resides in the Banda Aceh City area. The reason is that most of the followers of the Instagram account "kulineratjeh" are people of the city of Banda Aceh who usually look for the latest culinary information in Banda Aceh through the "kulineratjeh" Instagram account. In addition, some businesses that promote through the Instagram account "kulineratjeh" are also located in the Banda Aceh city area.

To obtain $80 \%$ at $5 \%$ alpha, the number of sample for each indicator is at least 5 samples or a maximum of 10 samples for the estimation model. The number of indicators in the model was 26 indicators, and then multiplied by 8 , the number of samples produced is 208 samples. The author's reason why in this research each indicator was multiplied by 8 is that it has met the criteria/requirements in selecting the sample size.

Data were collected using a questionnaire. In this research, the questionnaire used was an electronic questionnaire using a google form by distributing the questionnaire link to respondents via Instagram or other social media. Data was measured using a Likert scale. The data analysis method used was the MRA (Moderate Regression Analysis) method or often called the Moderated Hierarchical Regression Analysis(Baron \& Kenny, 1986).

\section{RESULT AND DISCUSSION}

\section{Direct Effect}

The results of the analysis of the influence of e-WOM quality, e-WOM quantity, and reviewer expertise on buying intentions can be seen in Table 1 below.

Table 1. Results of Direct Effect Hypothesis Test

\begin{tabular}{|c|c|c|c|c|c|c|}
\hline \multirow{2}{*}{\multicolumn{2}{|c|}{ Model }} & \multicolumn{2}{|c|}{$\begin{array}{l}\text { Unstandardized } \\
\text { Coefficients }\end{array}$} & \multirow{2}{*}{\begin{tabular}{|l}
$\begin{array}{l}\text { Standardized } \\
\text { Coefficients }\end{array}$ \\
Beta \\
\end{tabular}} & \multirow[t]{2}{*}{$t$} & \multirow[t]{2}{*}{ Sig. } \\
\hline & & B & Std. Error & & & \\
\hline \multirow{4}{*}{1} & (Constant) & 2.640 & .125 & & 21.047 & .000 \\
\hline & $\begin{array}{l}\text { Quality of E- } \\
\text { WOM }\end{array}$ & .076 & .025 & 177 & 3.031 & .003 \\
\hline & $\begin{array}{l}\text { Quantity of E- } \\
\text { WOM }\end{array}$ & .163 & .039 & .355 & 4.226 & .000 \\
\hline & $\begin{array}{l}\text { Reviewer } \\
\text { Expertise }\end{array}$ & .100 & .029 & .287 & 3.430 & .001 \\
\hline
\end{tabular}

a. Dependent Variable: Buying Intention

Source: Primary Data, 2021 (processed). 
According to(Hairet al., 2018)if the research uses a Likert scale, then the regression coefficient used is the standardized coefficient value, where the constant value does not need to be interpreted. Based on table 1, a linear equation can be drawn as follows:

$\mathrm{Y}=0,177 \mathrm{X}_{1}+0,355 \mathrm{X}_{2}+0,287 \mathrm{X}_{3}$

So from this equation, it can be explained that the regression coefficient of e-WOM quality (X1) is positive (0.177), meaning that the bigger and better the quality of e-WOM, the Instagram "kulineratjeh" account will increase buying intention. The regression coefficient for the quantity of e-WOM (X2) is positive (0.355) meaning that if the quantity of e-WOM increases, it will increase consumers' buying intentions for products promoted on the Instagram account "kulineratjeh". The regression coefficient of the reviewer's expertise (X3) is positive (0.287), meaning that if the reviewer's expertise increases, the consumer's buying intention for products promoted on the "kulineratjeh" Instagram account will also increase.

For the analysis of the correlation coefficient and also the analysis of determination for the independent variable $(\mathrm{X})$ to the dependent variable $(\mathrm{Y})$, the results can be seen from the following table:

Table 2. Correlation and Determination of Direct Effect

\begin{tabular}{|l|l|l|l|l|}
\hline $\begin{array}{l}\text { Mode } \\
\mathbf{l}\end{array}$ & $\mathbf{R}$ & $\begin{array}{l}\mathbf{R} \\
\text { Square }\end{array}$ & Adjusted R Square & $\mathbf{F}$ \\
\hline 1 & $.628^{\mathrm{a}}$ & .394 & .385 & 44.236 \\
\hline
\end{tabular}

Source: Primary Data, 2021 (processed).

From the test results in table 2 , the resulting $\mathrm{R}$ value is 0.628 , which means that there is a positive relationship between the variables of e-WOM quality (X1), e-WOM quantity (X2), and reviewer expertise (X3) on buying intention (Y) with closeness relationship worth 62.8\%. From the results of the analysis of the coefficient of determination, the R Square value of 0.394 explains that the variable quality of e-WOM (X1), quantity of e-WOM (X2), and reviewer expertise (X3) affect buying intention (Y) by 39.4\%, while the value of the residual of the role of the variable is $60.6 \%$. The residual value indicates the existence of several other factors that can affect the buying intention variable. According to research conducted by(Nasiruddin \& Hashim, 2015)explained that consumer reactions to the evolving e-WOM also influenced buying intentions. According to other research conducted by(Semuel \& Lianto, 2014), in addition to eWOM and brand image, another factor that can influence consumers' buying intentions is the brand trust variable. Where the brand trust variable is not a variable discussed in this research.

In table 2 there is a statistical test for $\mathrm{F}$ or commonly called the Analysis of Variance (ANOVA). According to(Ghozali, 2018), The F test shows whether all the independent variables included in the model have a joint effect on the dependent variable, with a significance value of $<0.05$. This ANOVA test or $F$ test produces a calculated $F$ value of 44.23 with a significance level of 0.000 because the significance probability is much smaller than 0.05 , so this regression model can be used to predict buying intention.

\section{Moderation Effect Test}

The results of the analysis of the effect of e-WOM quality, e-WOM quantity, and reviewer 
International Journal of Business Management and Economic Review

Vol. 4, No. 04; 2021

ISSN: 2581-4664

expertise on buying intentions with the brand image as a moderating variable can be seen in table 3 below.

Table 3. Results of Moderation Hypothesis Test

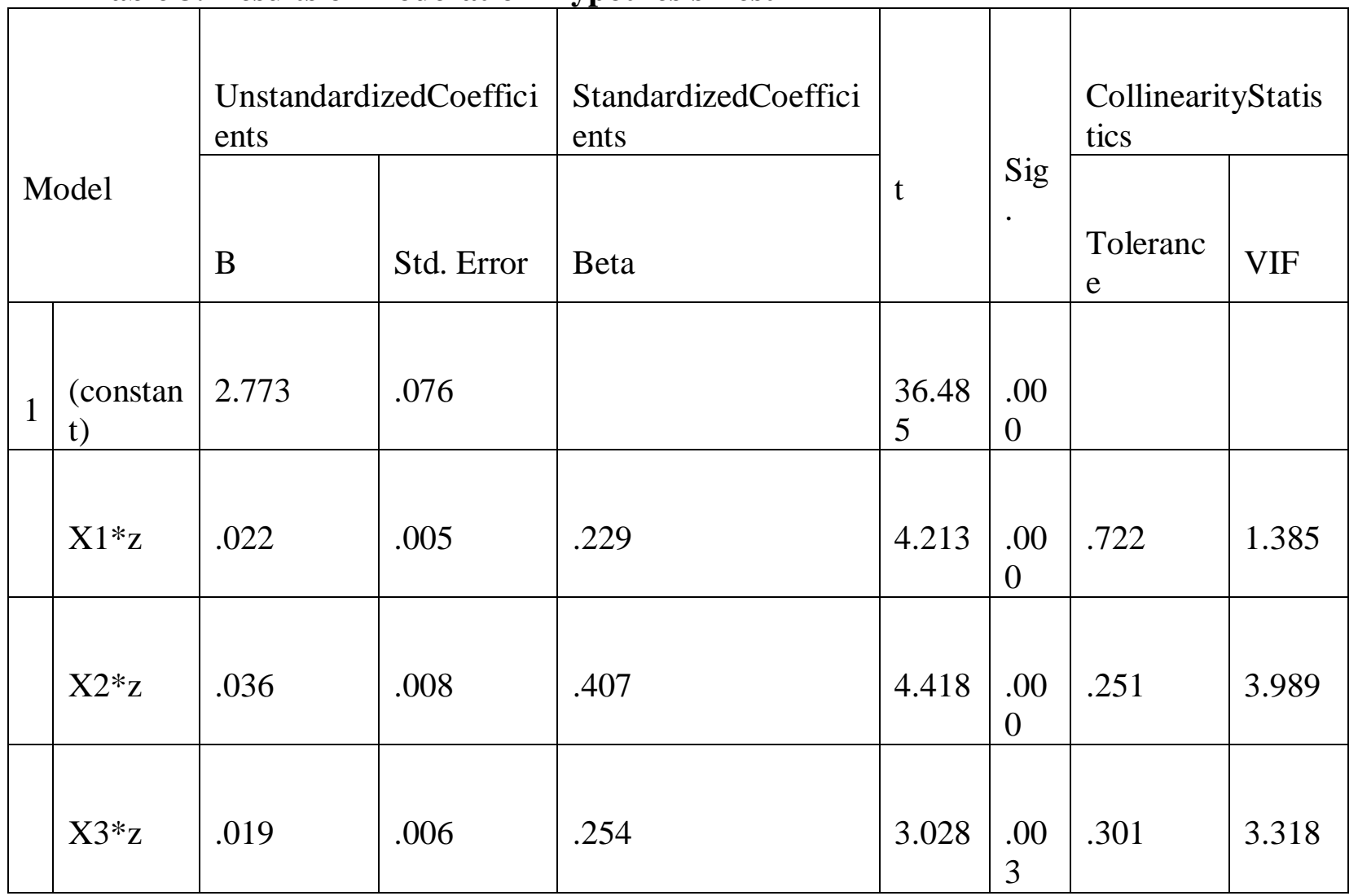

a.Dependent Variable: Buying intention

Source: Primary Data, 2021 (processed).

Based on table 3 above, the linear equation line is as follows:

$Y=0,177 X_{1}+0,355 X_{2}+0,287 X_{3}+1,98 Z+0,229 X_{1} Z+0,407 X_{2} Z+0,254 X_{3} Z$

From this equation, it can be explained that the regression coefficient of the independent variable after entering the moderating variable, there is a change, namely the quality of e-WOM (X1) which is moderated by brand image (Z). WOM and with a good brand image on the "kulineratjeh" instagram account, it will increase consumer buying intentions. The regression coefficient of e-WOM quantity (X2) moderated by brand image (Z) is positive (0.407), meaning that the higher the quantity of e-WOM and the presence of a good brand image on the Instagram account "kulineratjeh", it can increase consumer buying intentions.

The regression coefficient of the reviewer's expertise (X3) moderated by the brand image $(\mathrm{Z})$ is positive (0.254), meaning that the better the reviewer's expertise and the presence of a good brand image on the "kulineratjeh" Instagram account, it can increase consumer buying intentions. The next step is to assess the results of the correlation analysis of determination by using the adjusted $\mathrm{R}$ square. The results of the correlation and determination analysis between 
International Journal of Business Management and Economic Review

Vol. 4, No. 04; 2021

ISSN: 2581-4664

the quality of e-WOM, quantity of e-WOM, and the reviewer's expertise on buying intention with the brand image as the moderating variable are as follows:

Table 4. Correlation and Determination of Moderation Effect

\begin{tabular}{|l|l|l|l|l|}
\hline Model & $\mathrm{R}$ & R Square & $\begin{array}{l}\text { Adjusted } \\
\text { Square }\end{array}$ & $\begin{array}{l}\text { Std. Error of } \\
\text { theEstimate }\end{array}$ \\
\hline 1 & $.752^{\mathrm{a}}$ & .566 & .559 & .163 \\
\hline
\end{tabular}

Source: Primary Data, 2021 (processed).

In table 4 above, it can be seen that the correlation coefficient $(\mathrm{R})$ is 0.752 which explains that there is a positive relationship between the quality of e-WOM (X1), the quantity of e-WOM $(\mathrm{X} 2)$, and the reviewer's expertise $(\mathrm{X} 3)$ to buying intention $(\mathrm{Y})$ with the brand image $(\mathrm{Z})$ as a moderating variable with a close relationship of $75.2 \%$. Furthermore, the value of the coefficient of determination (R Square) is 0.566 which explains that the quality of e-WOM (X1), quantity of e-WOM (X2), and reviewer's expertise (X3) in increasing buying intention with the brand image variable $(\mathrm{Z})$ is $56,6 \%$, while the residual value (residual value) is $43.4 \%$, which means it is influenced by other variables.

\section{Discussion Per Hypothesis}

The following is a description of the relationship between the variables of e-WOM quality (X1), e-WOM quantity (X2), and reviewer expertise (X3) on buying intention with brand image as a moderating variable after factor analysis, which can be considered in the following framework:

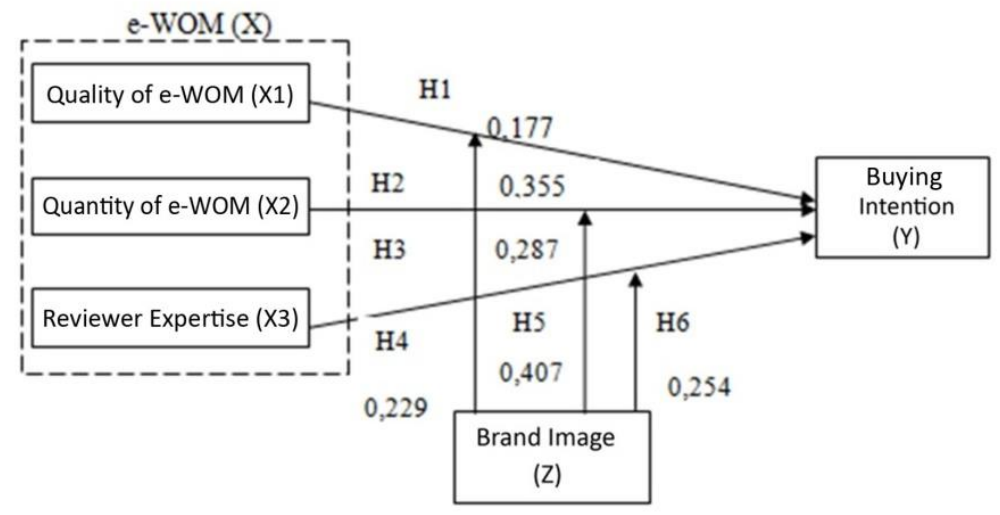

Figure 2. Hypothesis Testing Results

Based on the previous table 1 which explains the direct influence of the independent variable on the dependent variable, it can be seen that the e-WOM quality variable (X1) has a positive regression coefficient beta value of 0.177 with a probability of $<0.05$, which is worth 0.003 so that it proves that hypothesis 1 be accepted. This means that the quality of e-WOM (X1) significantly affects buying intention. This is in line with previous research by(Jalilvand \& 


\section{International Journal of Business Management and Economic Review}

Vol. 4, No. 04; 2021

ISSN: 2581-4664

Samiei, 2012), (Lin et al., 2013)which resulted that e-WOM significantly affects buying intention.

H1 :The quality of the e-WOM Instagram account "kulineratjeh" has an effect on consumers' buying intentions (accepted)

Furthermore, the e-WOM quantity variable (X2) has a positive regression coefficient beta value, which is 0.355 with a probability $<0.05$, which is 0.000 so that it proves that hypothesis 2 is accepted. This means that the quantity of e-WOM (X2) Instagram account "kulineratjeh" significantly affects buying intention. This is also in line with the results of research conducted by(Chevalier \& Mayzlin, 2006), (Lin et al., 2013)which stated that a large number of comments on an online review is able to influence consumers in forming buying intentions. This is because these comments are considered to represent the performance of the product in the market, so that consumers become more confident and the risk of mistakes in buying the product can also be minimized.

H2: The quantity of e-WOM on the Instagram account "kulineratjeh" has an effect on consumers' buying intentions (accepted)

The reviewer's expertise variable (X3) has a positive regression coefficient beta value, which is 0.287 with a probability of $<0.05$, which is 0.001 so that it proves that hypothesis 3 is accepted. This means that the reviewer's expertise (X3) "kulineratjeh" Instagram account significantly influences buying intention. This is following the results of research conducted by(Huang \& Chen, 2006), who stated that the reviewer's expertise in submitting reviews or online reviews was able to attract the attention of other users to and eventually adopt the information to finally influence consumers in making purchasing decisions. This is also following the results of research conducted by(Lin et al., 2013)who said that there was a positive influence of the expertise of e-WOM reviewers on consumers' buying intentions.

H3: The skill of sending the Instagram account "kulineratjeh" has an effect on consumers' buying intentions (accepted)

Based on table 3, it can be seen that the value of the variable quality of e-WOM (X1) which is moderated by brand image has a positive regression coefficient beta value of 0.229 , indicating that the quality of e-WOM has a positive effect on brand image. Based on table 3, the research model is obtained as follows:

$\mathrm{Y}=0,177 \mathrm{X}_{1}+0,229 \mathrm{X}_{1} * \mathrm{Z}$

Based on the results of testing the moderating effect, it is known that the quality of the eWOM Instagram account "kulineratjeh" significantly affects product buying intentions. Furthermore, a brand image acts as a significant moderating variable on buying intention. The moderating variable between the quality of e-WOM and brand image on consumer buying intentions is an estimated value of 0.229 or a higher moderating value than without moderation, which is 0.117 so that with the moderating variable it will increase consumers' buying intentions for the products in the instagram account "kulineratjeh " Thus, the moderating effect can be categorized as Quasi Moderation. Quasi moderation is a variable that moderates the relationship between the independent variable and the dependent variable which is also an independent 


\section{International Journal of Business Management and Economic Review}

Vol. 4, No. 04; 2021

ISSN: 2581-4664

variable. This means that the quality of e-WOM will still be able to increase consumer buying intentions with the brand image variable as a moderating variable. So that the fourth hypothesis in this research can be accepted. Thus the brand image can strengthen the quality of e-WOM on the intention to buy products that are on the Instagram account "kulineratjeh".

H4: Brand Image moderates the effect of e-WOM quality on the Instagram account "kulineratjeh" on consumer buying intentions (accepted).

Based on table 3, it can be seen that the equation lines for the variable quantity of e-WOM (X2) and brand image as moderating variables are as follows:

$\mathrm{Y}=0,355 \mathrm{X}_{2}+0,407 \mathrm{X}_{2} \mathrm{Z}$

Based on the test results, it is known that the quantity of e-WOM significantly affects product buying intentions. Furthermore, brand image also moderates the quantity of e-WOM on consumer buying intentions. It can be seen from the equation that the estimated value using the moderating variable $(0.407)$ is higher than the estimated value without a moderating variable $(0.355)$ so that the moderating effect can increase buying intention. Thus, the moderating effect can be categorized as Quasi Moderation. Thus, it can be concluded that brand image can strengthen and moderate the quantity of e-WOM of the Instagram account "kulineratjeh" towards buying intention. So that the fifth hypothesis in this research can be accepted.

H5: Brand Image moderates the effect of the quantity of e-WOM on the Instagram account "kulineratjeh" on consumers' buying intentions (accepted).

Based on table 3, it can be seen that the equation line for the reviewer's expertise variable (X3) and brand image as the moderating variable is as follows:

$\mathrm{Y}=0,287 \mathrm{X}_{3}+0,254 \mathrm{X}_{2} * \mathrm{Z}$

Based on the results of testing the moderating effect of brand image, it is known that the skill of the reviewer significantly affects the buying intention of the product in the "kulineratjeh" Instagram account. Furthermore, brand image $(\mathrm{Z})$ is significant to buying intention and the result of exogenous multiplication with moderation (interaction 2) is significant to buying intention. In this research, the influence of the reviewer's expertise variable on buying intention with the brand image as a moderating variable obtained an estimated value of 0.254. In this case, the value of the moderating effect is lower than the direct influence of the reviewer's expertise on the buying intention variable without a brand image as a moderating variable with an estimated value of 0.287 , so that with the moderating variable, the influence of the reviewer's expertise will actually reduce consumers' buying intentions for the product. is on the Instagram account "kulineratjeh". However, the influence between before there is moderation and there is moderation between the reviewer's expertise and brand image has a positive and significant effect. Thus, the moderating effect can be categorized as Quasi Moderation. This means that without moderation, namely brand image, the reviewer's expertise on buying intention will remain influential without having to go through brand image. Thus, the sixth hypothesis in this research is accepted. It can be concluded that brand image can strengthen the reviewer's expertise towards the buying intention of the product on the instagram account "kulineratjeh".

H6: Brand Image moderates the influence of the skill of the reviewer of the Instagram account "kulineratjeh" on consumers' buying intentions (accepted). 
International Journal of Business Management and Economic Review

Vol. 4, No. 04; 2021

ISSN: 2581-4664

\section{CONCLUSION}

Based on the results of this research analysis, the conclusions that can be drawn are as follows:

1) The quality of e-WOM, the quantity of e-WOM, and the expertise of the reviewer are dimensions of e-WOM which are also as predictors of buying intention on products promoted on the instagram account "kulineratjeh". So before people make a purchase, they first consider the three predictors. Of the three predictors, the variable quantity of e-WOM is the most dominant variable in influencing buying intention.

2) Brand image moderates the effect of e-WOM quality, e-WOM quantity, and reviewer expertise on buying intentions on products promoted on the instagram account "kulineratjeh". The existence of a brand image can help strengthen the quantity of e-WOM and the quality of e-WOM on buying intentions.

These findings become a new premise for related causality theories so that this model of increasing buying intention can be applied to the development of products promoted on the "kulineratjeh" Instagram account. Brand Image which is proven to be moderating, which can function as a moderator between the predictor variables and the buying intention variable, and can also be a predictor to influence the increase or decrease in buying intention on products promoted on the "kulineratjeh" Instagram account. For further researchers, it is hoped that they can develop this tested model by adding other moderating variables such as brand awareness and gender.

Several recommendations were generated from the results of this research. The Instagram account owner "kulineratjeh" is expected to be able to prepare a strategy in attracting culinary entrepreneurs in Banda Aceh to want to promote their business. It is hoped that the quality of promotions and reviews carried out on the "kulineratjeh" Instagram can be maintained so that it can strengthen the brand image of the "kulineratjeh" Instagram account which will ultimately increase consumer buying intentions. And, for the people of Banda Aceh who want to visit a cafe or restaurant in Banda Aceh that has never been visited before, it is advisable to seek information in advance about all aspects on the instagram "kulineratjeh". This information search is done so that consumers have a good enough reference before making a purchase.

\section{REFERENCES}

Bambauer-Sachse, S., \& Mangol, S. (2011). Brand equity dilution through negative online wordof-mouth communication. Journal of Retailing and Consumer Services, 18(1), 38-45. https://doi.org/https://doi.org/10.1016/j.jretconser.2010.09.003

Baron, R. M., \& Kenny, D. A. (1986). The Moderator-Mediator Variable Distinction in Social Psychological Research: Conceptual, Strategic, and Statistical Considerations. Journal of Personality and Social Psychology, 51(6), 1173-1182.

Chevalier, J. A., \& Mayzlin, D. (2006). The Effect of Word of Mouth on Sales: Online Book Reviews. Journal of Marketing Research, 43(3), 345-354. https://doi.org/https://doi.org/10.1509/jmkr.43.3.345

Ghozali, I. (2018). Aplikasi analisis multivariate dengan program IBM SPSS 25 (9th ed.). Semarang: Badan Penerbit Universitas Diponegoro.

Goldsmith, R. E., \& Horowitz, D. (2006). Measuring Motivation for Online Opinion Seeking. 
International Journal of Business Management and Economic Review

Vol. 4, No. 04; 2021

ISSN: $2581-4664$

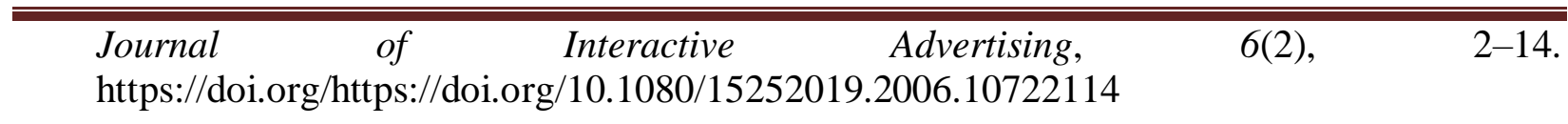

Hair, J. F., Babin, B. J., Anderson, R. E., \& Black, W. C. (2018). Multivariate Data Analysis (8th Ed.). London: Pearson.

Huang, J.-H., \& Chen, Y.-F. (2006). Herding in online product choice. Psychology and Marketing, 23(5), 413-428. https://doi.org/https://doi.org/10.1002/mar.20119

Jalilvand, M. R., \& Samiei, N. (2012). The effect of electronic word of mouth on brand image and purchase intention: An empirical study in the automobile industry in Iran. Marketing Intelligence \& Planning, 30(4), 460-476. https://doi.org/10.1108/02634501211231946

Kotler, P., \& Armstrong, G. (2008). Prinsip-prinsip Pemasaran (12th ed.). Jakarta: Erlangga.

Kotler, P., \& Armstrong, G. (2017). Principles of Marketing (17th ed.). London: Pearson.

Kotler, P., \& Keller, K. L. (2018). Marketing Management, Global Edition (15th edition). Harlow, United Kingdom: Pearson.

Lin, C., Wu, Y.-S., \& Chen, J.-C. V. (2013). Electronic Word-of-Mouth: The Moderating Roles Product Involvement and Brand Image. International Conference on Technology Innovation and Industrial Management. Proceedings of 2013 International Conference on Technology Innovation and Industrial Management, 29-47. Phuket, Thailand: TIIM.

Nasiruddin, K., \& Hashim, H. (2015). Electronic Word of Mouth: Exploring Consumer Reactions and Purchase Intention. Journal of Global Business and Social Entrepreneurship (GBSE), 1(1), 85-93.

Park, D.-H., \& Kim, S. (2008). The effects of consumer knowledge on message processing of electronic word-of-mouth via online consumer reviews. Electronic Commerce Research and Applications, 7(4), 399-410. https://doi.org/https://doi.org/10.1016/j.elerap.2007.12.001

Sangadji, E. M., \& Sopiah. (2014). Perilaku Konsumen : Pendekatan Praktis. Yogyakarta: andi Offset.

Schiffman, L., \& Kanuk, L. (2010). Consumer Behavior (11th ed.). London: Pearson.

Schiffman, L., \& Wisenblit, J. L. (2019). Consumer Behavior (12th ed.). New Jersey: Pearson.

Semuel, H., \& Lianto, A. S. (2014). Analisis eWOM, Brand Image, Brand Trust dan Minat Beli Produk Smart Phone di Surabaya. Jurnal Manajemen Pemasaran, 8(2), 7-54. https://doi.org/https://doi.org/10.9744/pemasaran.8.2.7-54

Sugiyono. (2017). Metode Penelitian Bisnis. Bandung: Alfabeta.

Tariq, M. I., Nawaz, M. R., Nawaz, M. M., \& Butt, H. A. (2013). Customer Perceptions about Branding and Purchase Intention: A Study of FMCG in an Emerging Market. Journal of Basic and Applied Scientific Research, 3(2), 340-347. 